\title{
ZÁŽITKY S JARMILOU EMMEROVOU
}

\author{
PhDr. PAVLA JONSSONOVÁ SLABÁ, Ph.D. \\ PŘEKLADATELKA, HUDEBNICE, VYSOKOŠKOLSKÁ \\ PEDAGOŽKA
}

Moje vzpomínky na doktorku Jarmilu Emmerovou, milovanou učitelku na Katedře překladatelství a tlumočnictví FF UK, jsou stále živé. Od první chvíle v prvním ročníku, kdy vstoupila do dveří a usmála se na nás na přivítanou, až po závěrečnou státní zkoušku, při které nás laskavě povzbuzovala.

Zásadní na jejím přístupu k nám studentům bylo, že nás brala jako kolegy, kteří jsou inteligentní a škola je maximálně zajímá. Roky, kdy jsem studovala, 1980-1985, byly dobou ideologickou, nasycenou marxismem-leninismem. Obor anglického jazyka a literatury v ní působil jako diverze. Sice jsme za celou dobu studia nepotkali jediného rodilého mluvčího (s výjimkou stáže v Lipsku), ale Jarmila Emmerová v propojení s vyučujícími na anglistice a amerikanistice, Martinem Hilským a Radoslavem Nenadálem, na jejichž přednášky jsme chodili v opojení, byli jako majáky signalizující, že se v moři socialismu lze zachytit i jiných hodnot. Věděli jsme, že postavení Jarmily Emmerové na katedře a na UK je problematické kvůli jejím názorům na okupaci roku 1968 a také kvůli jejímu přátelství s Josefem Škvoreckým, ale to ji v našich očích jen glorifikovalo.

Vzbuzovala dobrou náladu, vždy elegantní a graciézní. Její krásná angličtina v té těžké době vytvářela pocit, že jsme spoluúčastníky něčeho velkého a vznešeného. Její hodiny byly velmi praktické, třeba na překladatelském prosemináři v prvním ročníku nás seznamovala se synonymickými řetězci, stále se mi vybavuje modify-alter-change. Faktická výuka se pojila s vyprávěním o Anglii. Vždycky ř́kala „jak stále odkládáte svou cestu do Anglie“, což v situaci, kdy nikdo z nás o něčem takovém nemohl ani snít, působilo jako shrnutí našeho tehdejšího údělu. Zároveň jsme věděli, že je slavná překladatelka Raye Bradburyho, Carson McCullersové, Erskina Caldwella, Thomase Hardyho, Arthura C. Clarka a dalších velkých spisovatelů. Tenkrát pracovala na překladu knihy Poslední kabriolet Anthonyho Myrera a dělila se s námi o různá úskalí, se kterými se setkávala. Na nás to působilo magicky, jako bychom byli přizváni k vytváření překladu. Její péče o češtinu a pečlivost, s níž přenášela anglickou a americkou realitu do českého kontextu, zavazovala i nás. Znala významné teoretiky a doplňovala naše vzdělání o Pražském lingvistickém kroužku. Měla knihy, které nám obětavě zapůjčovala v době, kdy nebyly v knihovnách a ani jinak k sehnání; např́klad J. C. Catforda a jeho teorii překladu. To ona nás naučila studium milovat. Také nás zasvětila do čtení Knižních novinek, které tenkrát vycházely každý čtvrtek, jenž býval velkou a očekávanou knižní událostí. Společně s námi hodnotila vydavatelské počiny. 
Já v té době zažívala první koncerty se svou punkovou kapelou Plyn. Na úplně první ve studentském klubu Euridika na Petřinách jsem pozvala i Jarmilu Emmerovou. A ona prrišla, i s manželem. U vchodu se jí ptali: a nespletla jste se, opravdu chcete jít na takovýto punkový koncert? Byla to pro mě velká pocta. To jsem ještě nevěděla, že Jarmila Emmerová měla $\mathrm{k}$ hudbě tak blízko, že ji původně chtěla studovat.

Ve druhém ročníku nás Jarmila Emmerová doprovázela na třítýdenní studijní cestě do Východního Německa. Ve dne byla skvělou společnicí, která pochopitelně mluvila - na rozdíl od nás - německy, a mohla nám tak vypomoci s domluvou. Po večerech s námi procvičovala složitá gramatická souvětí: z luštění komplikovaných sousledností pod jejím dohledem se stávala zábava a napínavé dobrodružství logiky. V Lipsku jsme se spřátelili s rodilým mluvčím Johnem Brownem, a když jsme ho pozvali na návštěvu do Prahy, Jarmila Emmerová ho ubytovala u sebe a zcela samozřejmě pro nás všechny uspořádala anglistický večírek.

Neváhala jsem ani vteřinu, kdo bude vedoucí mé diplomové práce. Napřed jsme debatovaly o tom, zda budu psát o Williamu Burroughsovi, nebo ne, a nakonec jsme se shodly, že Bob Dylan a jeho překlady do češtiny jsou schůdné téma. Její pomoc byla nedocenitelná: u ní doma při čaji jsme četly jednotlivé věty a ona jim dávala křídla. $Z$ diplomového semináře si pamatuji, jak nás zasvěcovala do kompozice práce, různých úskalí úvodu, kapitol i závěru, a přitom nám rozdávala třeba mandarinky (tenkrát nedostatkové zboží).

Samozřejmě jsem po studiu toužila zůstat $v$ kontaktu se ženou, která se stala mým vzorem. Když nám se skupinou Dybbuk v roce 1987 vyšlo malé $\mathrm{EP}$, hrdě jsem jí ho donesla domů. Setkávaly jsme se také na večírcích britské a americké ambasády. Po roce 1989 se Jarmila Emmerová stala zaslouženě předsedkyní Obce překladatelů a média se o ni konečně začala zajímat formou objevných rozhovorů. Byli jsme na ni velmi hrdí.

Setkávání s doktorkou Emmerovou je dodnes pro mne a mé spolužáky a kolegy, Martina Machovce, Vladimíru Žákovou, Tomáše Míku a Evu Klimentovou, důležitou součástí našich životů. Mé dceři Noemi přinesla po jejím narození na setkání u nás doma svůj překlad slavné knihy Jirka postrach rodiny a nám všem svůj vlastní citronový koláč. Lahůdky na našich setkáních jsou ovšem hlavně duchovní - trávíme dodnes vždy několik hodin hovorem o kulturních událostech, o anglické i americké literatuře nebo jen o našich osobních př́bězích.

Jarmila Emmerová je $\mathrm{v}$ našich životech nezastupitelná. Přejeme jí $\mathrm{k}$ devadesátým narozeninám všechno nejlepší a pevné zdraví do dalších let a nám všem další společná inspirující setkání. 